\title{
Teaching NeuroImages: Trigeminal Ganglia Hypoplasia as Imaging Clue for the Diagnosis of Gómez-López-Hernández Syndrome
}

Eduardo Perrone, MD, Stênio Burlin, MD, Vânia D’Almeida, PhD, Ana Beatriz Alvarez Perez, PhD, Nara Lygia de Macena Sobreira, PhD, Victor Rebelo Procaci, MD, Marcela Amaral Avelino Jacobina, MD, Orlando G. Barsottini, MD, PhD, and José Luiz Pedroso, MD, PhD

Neurology ${ }^{\circledR}$ 2021;96:e1593-e1594. doi:10.1212/WNL.0000000000011158

Figure 1 Brachycephaly, Midface Hypoplasia, Strabismus, and Left Unilateral Parietal Alopecia in Gómez-López-Hernández Syndrome

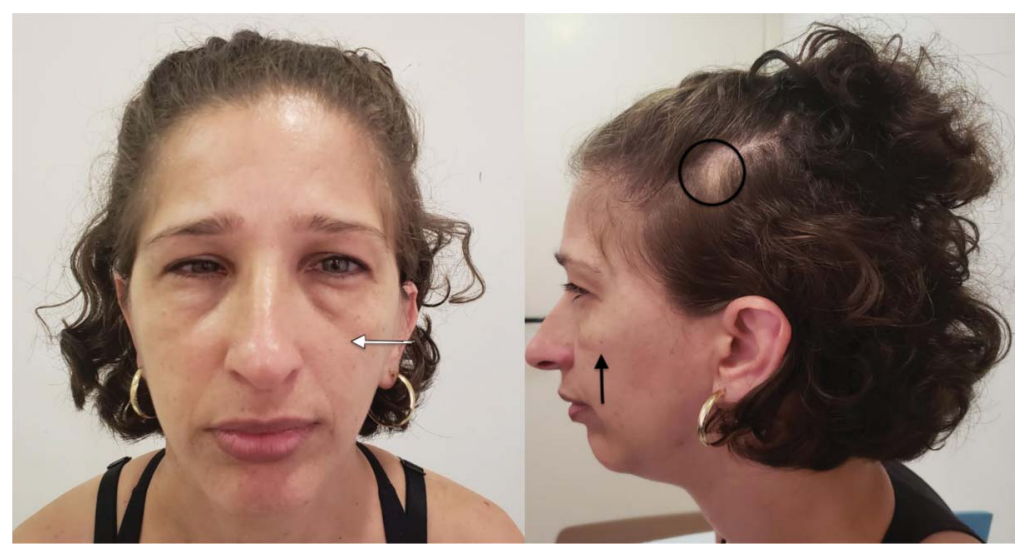

Patient with Gómez-López-Hernández syndrome. Frontal and lateral view of the face shows brachycephaly, midface hypoplasia, strabismus, and left unilateral parietal alopecia.

A 42-year-old woman presented with ataxia and numbness in her face since childhood. Her parents were nonconsanguineous. Examination showed ataxia, alopecia, absent corneal reflex, and hypoesthesia in right trigeminal territory (figure 1). Brain MRI disclosed rhombencephalosynapsis and trigeminal nerve hypoplasia (figure 2). Exome sequencing excluded other genetic diseases. Gómez-López-Hernández syndrome (GLHS) was diagnosed.

GLHS is a rare and maybe underdiagnosed neurocutaneous disorder (with few cases described) characterized by ataxia, alopecia, trigeminal anesthesia, rhombencephalosynapsis, and brachyturrycephaly. Genetics of GLHS is unknown. ${ }^{1}$ Brain imaging includes rhombencephalosynapsis, which may occur in other syndromes. Trigeminal ganglia hypoplasia is a neuroimaging clue for the diagnosis of GLHS. ${ }^{2}$

\section{Study Funding}

No targeted funding reported.

\section{Correspondence}

Dr. Perrone

eperrone@unifesp.br

\section{MORE ONLINE}

$\rightarrow$ Teaching slides

links.lww.com/WNL/ B270 
Figure 2 MRI Shows Rhombencephalosynapsis and Hypoplasia of the Right Trigeminal Nerve in Gómez-López-Hernández Syndrome
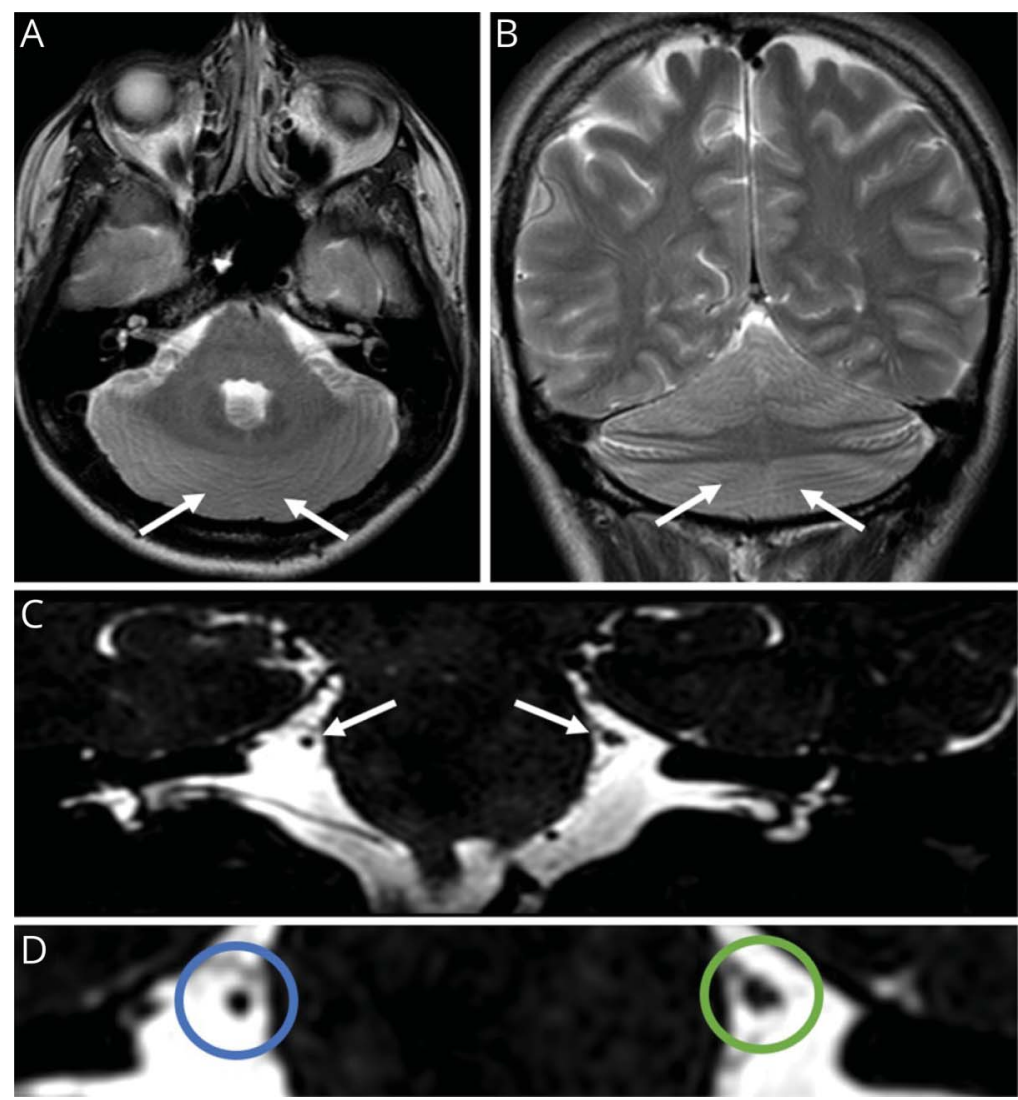

Axial (A) and coronal (B) T2-weighted brain MRI shows rhombencephalosynapsis, characterized by absence of vermis, with fusion of the cerebellar hemispheres (arrows). (C) Coronal FIESTA shows hypoplasia of the right trigeminal nerve (arrows). (D) Expanded imaging highlights hypoplasia of the right trigeminal nerve (blue circle) that is thinner than the normal contralateral nerve (green circle).

\section{Disclosure}

The authors declare no disclosures relevant to the manuscript. Go to Neurology.org/N for full disclosures.

\section{Appendix Authors}

\begin{tabular}{lll}
\hline Name & Institution & Contribution \\
\hline $\begin{array}{l}\text { Eduardo } \\
\text { Perrone, MD }\end{array}$ & $\begin{array}{l}\text { Universidade } \\
\text { Federal de São } \\
\text { Paulo, Brazil }\end{array}$ & $\begin{array}{l}\text { Designed and conceptualized } \\
\text { the case report, collected the } \\
\text { data, wrote the first draft, } \\
\text { revised the manuscript }\end{array}$ \\
\hline $\begin{array}{l}\text { Stênio Burlin, } \\
\text { MD }\end{array}$ & $\begin{array}{l}\text { Universidade } \\
\text { Federal de São }\end{array}$ & $\begin{array}{l}\text { Designed and conceptualized } \\
\text { the case report, collected the } \\
\text { data, revised the manuscript }\end{array}$ \\
\hline $\begin{array}{l}\text { Vaulo, Brazil } \\
\text { D'Almeida, PhD }\end{array}$ & $\begin{array}{l}\text { Universidade } \\
\text { Federal de São }\end{array}$ & $\begin{array}{l}\text { Designed and conceptualized } \\
\text { the case report, revised the } \\
\text { manuscript }\end{array}$ \\
\hline $\begin{array}{l}\text { Ana Beatriz } \\
\text { Alvarez Perez, } \\
\text { PhD }\end{array}$ & $\begin{array}{l}\text { Universidade } \\
\text { Federal de São }\end{array}$ & $\begin{array}{l}\text { Designed and conceptualized } \\
\text { the case report, revised the } \\
\text { manuscript }\end{array}$ \\
\hline $\begin{array}{l}\text { Nara Lygia de } \\
\text { Macena } \\
\text { Sobreira, PhD }\end{array}$ & $\begin{array}{l}\text { Johns Hopkins } \\
\text { University, }\end{array}$ & $\begin{array}{l}\text { Designed and conceptualized } \\
\text { the case report, revised the } \\
\text { manuscript }\end{array}$ \\
\hline
\end{tabular}

Appendix (continued)

\begin{tabular}{|c|c|c|}
\hline Name & Institution & Contribution \\
\hline $\begin{array}{l}\text { Victor Rebelo } \\
\text { Procaci, MD }\end{array}$ & $\begin{array}{l}\text { Universidade } \\
\text { Federal de São } \\
\text { Paulo, Brazil }\end{array}$ & $\begin{array}{l}\text { Designed and conceptualized } \\
\text { the case report, collected the } \\
\text { data, wrote the first draft, } \\
\text { revised the manuscript }\end{array}$ \\
\hline $\begin{array}{l}\text { Marcela Amaral } \\
\text { Avelino } \\
\text { Jacobina, MD }\end{array}$ & $\begin{array}{l}\text { Universidade } \\
\text { Federal de São } \\
\text { Paulo, Brazil }\end{array}$ & $\begin{array}{l}\text { Designed and conceptualized } \\
\text { the case report, collected the } \\
\text { data, revised the manuscript }\end{array}$ \\
\hline $\begin{array}{l}\text { Orlando G. } \\
\text { Barsottini, MD, } \\
\text { PhD }\end{array}$ & $\begin{array}{l}\text { Universidade } \\
\text { Federal de São } \\
\text { Paulo, Brazil }\end{array}$ & $\begin{array}{l}\text { Designed and conceptualized } \\
\text { the case report, revised the } \\
\text { manuscript }\end{array}$ \\
\hline $\begin{array}{l}\text { José Luiz } \\
\text { Pedroso, MD, } \\
\text { PhD }\end{array}$ & $\begin{array}{l}\text { Universidade } \\
\text { Federal de São } \\
\text { Paulo, Brazil }\end{array}$ & $\begin{array}{l}\text { Designed and conceptualized } \\
\text { the case report, collected the } \\
\text { data, wrote the first draft, } \\
\text { revised the manuscript }\end{array}$ \\
\hline
\end{tabular}

\section{References}

1. Perrone E, D’Almeida V, de Macena Sobreira NL, et al. Gómez-López-Hernández syndrome: a case report with clinical and molecular evaluation and literature review. Am J Med Genet Part A 2020;182.

2. Choudhri AF, Patel RM, Wilroy RS, et al. Trigeminal nerve agenesis with absence of foramina rotunda in Gómez-López-Hernández syndrome. Am J Med Genet 2015; 167A:238-242. 


\section{Neurology}

\section{Teaching NeuroImages: Trigeminal Ganglia Hypoplasia as Imaging Clue for the Diagnosis of Gómez-López-Hernández Syndrome}

Eduardo Perrone, Stênio Burlin, Vânia D'Almeida, et al.

Neurology 2021;96;e1593-e1594 Published Online before print November 9, 2020

DOI 10.1212/WNL.0000000000011158

This information is current as of November 9,2020

\begin{tabular}{|c|c|}
\hline $\begin{array}{l}\text { Updated Information \& } \\
\text { Services }\end{array}$ & $\begin{array}{l}\text { including high resolution figures, can be found at: } \\
\text { http://n.neurology.org/content/96/11/e1593.full }\end{array}$ \\
\hline References & $\begin{array}{l}\text { This article cites } 1 \text { articles, } 0 \text { of which you can access for free at: } \\
\text { http://n.neurology.org/content/96/11/e1593.full\#ref-list- } 1\end{array}$ \\
\hline Subspecialty Collections & $\begin{array}{l}\text { This article, along with others on similar topics, appears in the } \\
\text { following collection(s): } \\
\text { All Genetics } \\
\text { http://n.neurology.org/cgi/collection/all_genetics } \\
\text { Cerebellum } \\
\text { http://n.neurology.org/cgi/collection/cerebellum } \\
\text { Other neurocutaneous disorders } \\
\text { http://n.neurology.org/cgi/collection/other_neurocutaneous_disorders }\end{array}$ \\
\hline Permissions \& Licensing & $\begin{array}{l}\text { Information about reproducing this article in parts (figures,tables) or in } \\
\text { its entirety can be found online at: } \\
\text { http://www.neurology.org/about/about_the_journal\#permissions }\end{array}$ \\
\hline Reprints & $\begin{array}{l}\text { Information about ordering reprints can be found online: } \\
\text { http://n.neurology.org/subscribers/advertise }\end{array}$ \\
\hline
\end{tabular}

Neurology ${ }^{\circledR}$ is the official journal of the American Academy of Neurology. Published continuously since 1951, it is now a weekly with 48 issues per year. Copyright () 2020 American Academy of Neurology. All rights reserved. Print ISSN: 0028-3878. Online ISSN: 1526-632X.

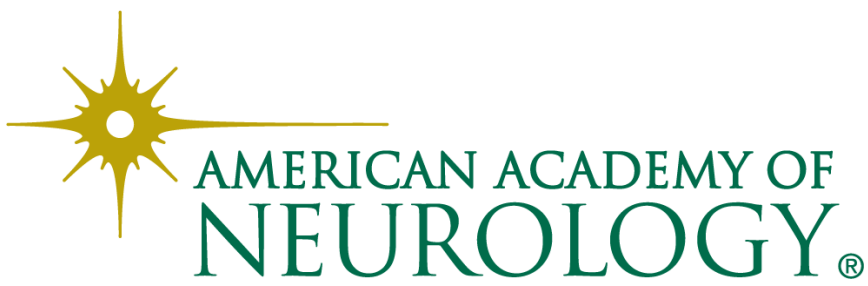

